\title{
Seven Stars of Heaven and Seven Shrines on Earth: The Big Dipper and the Hie Shrine in the Medieval Period
}

\section{Meri Arichi}

\begin{abstract}
The belief in Sannō, the kami of the Hie Shrine, evolved under the strong influence of Tendai Buddhism during the medieval period. Esoteric scriptures and ritual manuals related to astronomy and astrology encouraged the association of the seven stars of the constellation of the Big Dipper with the seven principal shrines at Hie. The hierarchical grouping of shrines in three units of seven suggests the theoretical input from the Buddhist monks of the Enryaku-ji to the development of the shrine. However the connection of stars and shrines was eradicated after the separation of temples and shrines (shinbutsu-bunri) carried out by the Meiji government in the late $19^{\text {th }}$ century, and little evidence of starrelated rituals at the shrine remains today. This paper examines the iconography of the Hie-Sannō Mandara from the Kamakura period in the collection of Saikyō-ji, and considers the significance of the Big Dipper in the context of the Hie-Sannō belief from visual and textual sources.
\end{abstract}

The significance of the constellation of the Big Dipper (J. Hokuto shichisei) 北斗七星 in Japan is evident from the rich variety of textual and visual sources dating back to the Asuka 飛鳥 period (542-645 CE). However, with the transmission of esoteric Buddhism in the early ninth century, knowledge of astronomy and astrology made a remarkable leap from a mystic belief to a more sophisticated Buddhist ritual system, and esoteric monks encouraged the dissemination of texts and rituals related to stars both in the Shingon 真言 and Tendai 天台 sects. The distinct ladle-like shape of the Big Dipper appears prominently in many star mandalas, suggesting the important role that the seven stars played in

Meri Arichi, 'Seven Stars of Heaven and Seven Shrines on Earth: The Big Dipper and the Hie Shrine in the Medieval Period', Culture and Cosmos, Vol. 10 no 1 and 2, Spring/ Summer and Autumn/Winter 2006, pp. 195-216.

www.CultureAndCosmos.com 
esoteric rituals. ${ }^{1}$ In this paper, I shall examine the iconography of HieSannō mandara 日吉山王曼茶羅 and consider the historical and theoretical backgrounds that were responsible for the identification of the seven stars of the Big Dipper with the seven principal shrines at Hie during the medieval period.

\section{The early images of the Hokuto shichisei in Japan}

One of the earliest examples of visual evidence that suggests the importance of the constellation of the Big Dipper in Japanese culture is a seventh century sword, shichisei ken 七星剣 (literally the sword of seven stars), handed down in the temple Shitennō-ji 四天王寺 in Osaka. The sword is traditionally believed as once a property of Prince Shōtoku 聖徳太子 (r. 593-622), the founder of the temple and a leading figure in the promotion of Buddhism. The blade of the sword is decorated with a motif of the seven stars, inlaid side by side with other motifs such as scrolling clouds and a stylized dragon head in gold and silver. The popularity of these motifs during the Asuka and Nara 奈良 periods can be surmised from the record Tódaiji kenmotsuchō 東大寺献物帳 (Records of the Treasures of the Tōdaiji temple), which lists several swords with similar motifs, including stars. ${ }^{2}$

A strong Chinese influence on the formation of Japanese culture is clearly visible in these motifs, which originate from ancient China, suggesting that the knowledge of astronomy and the related symbolism were an integral part of the wholesale adoption of Chinese culture. The Chinese astronomers divided the sky into five "palaces" (Ch. wu gong) 五宮, corresponding to the five cardinal directions, east, south, west, north, and the middle. The middle was the most important region, centring on the Polar Star, which was identified with the emperor. ${ }^{3}$ The

1 The term mandara is a Japanese corruption of the word mandala, originally a Sanskrit term which is compounded of two words, manda (circle, essence) and la (to attain). The mandala can be interpreted as a circle, a magic circle, the solar or lunar disc, a halo, or a group, which in Esoteric Buddhism came to be associated with graphic representations of Buddhist universe. The term mandara is used here in order to distinguish the works created in Japan from the Esoteric mandala of Indian origin.

2 See exhibition catalogue Shōtoku Taishi ten, Tokyo Metropolitan Museum, 2001, p. 90. 
Polar Star and the Big Dipper were already recognized as important astronomical elements in China before the transmission of Buddhism. According to the Shiji 史記, the Chinese History written by Shima Qian 司馬遷 in $91 \mathrm{BCE}$, the constellation of the Big Dipper, which revolves around the Polar Star, was regarded as the vehicle of the emperor. ${ }^{4}$ The motif of the seven stars on the sword, then, was perhaps interpreted by the temple as an appropriate symbol for someone as close to the imperial circle as Prince Shotoku, who was a nephew and the regent of the empress Suiko (r. 592-628).

Another early example is a lidded vessel in the shape of a terrapin, preserved in the Shōsō-in 正倉院, Nara. The small vessel is fashioned from a grey-blue serpentine, and the eyes of the terrapin are inlaied with red amber. On the back of its shell, seven silver circles are arranged in the shape of the constellation, and a golden line is inlayed to join the circles, clearly delineating the ladle shape (Fig. 1). This vessel is believed to represent the mystic terrapin that was presented to the emperor in 715, the first year of the Reiki 霊亀 era. The Shoku Nihongi 続日本紀, a history of Japan, describes that this terrapin had one red eye and one white eye, three spots on the neck similar to the three stars 三公 near the Polar Star, and the motif of the Big Dipper on its back. ${ }^{5}$ The change of the era name from Wadō 和銅 to Reiki (literally, 'mystic terrapin') in that year was the result of the appearance of this strange terrapin, suggesting the seriousness with which such an event was received as an important omen by the imperial house. These examples indicate that the stars of the Big Dipper were regarded as mystic and powerful forces that exerted influence on earth.

\section{Transmission of esoteric texts related to stars}

The transmission of esoteric Buddhism to Japan in the early ninth century had a profound effect on the course of Japanese Buddhism. Among the

3 Bonnet-Bidaud, Jean-Marc, and Praderie, Francoise, 'Star Chart on Silk Road: Astronomical Star Maps in Ancient China,' in Susan Whitfield with Ursula Sims-Williams (eds.), The Silk Road: Trade, Travel, War and Faith, London: The British Library, 2004, pp. 81-90.

4 Takeda Kazuaki, Hoshi Mandara no kenkyū, Kyoto: Hōzōkan, 1995, p. 53.

5 Hayashi On, Myōken bosatsu to Hoshi Manadara, Nihon no bijutsu 377 (1997), p. 26. 
vast number of esoteric scriptures brought by Japanese monks returning from a long period of study in China was the Suyao jing 宿曜経 (J. Sukuyo-kyō), the principal Buddhist text on the theory of stars. ${ }^{6}$ This scripture, which is generally regarded as a Chinese translation of an Indian text adapted by the monk Amoghavajra (J. Fukū 不空, 705-774) and his Chinese disciples, characteristically incorporated the theory of zodiac of Hellenistic origin and the idea of twenty-eight Lunar Mansions 二十八宿 originating from India. ${ }^{7}$ Such Buddhist scriptures related to astronomy and astrology incorporated the advanced scientific knowledge that flourished in the Tang capital, Chang'an. The thriving cosmopolitan environment encouraged the exchange of knowledge and ideas as well as the trade in material riches between the West and the East.

The astonishing accuracy with which the astronomers observed and charted the night sky during the Tang dynasty is evident in the early eighth century star chart discovered by Aurel Stein in 1907 among the thousands of manuscripts stored in the Library cave (Cave 17) at Dunhuang. The manuscript, now in the British Library, includes thirteen separate diagrams that show 1,345 stars grouped in 257 groups. $^{8}$ The thirteenth diagram depicts the northern circumpolar region with the Chinese characters for Northern Pole 北極 in the centre, and the constellation of the Big Dipper clearly marked and labelled Hokuto 北斗 below (Fig. 2). Scientific observation and Daoist traditions were combined with Buddhist ideas when esoteric Buddhist scriptures, such as the Suyai jing, were translated and adapted in China. The identification of the emperor with the Polar Star, and the important role assigned to the seven stars of the Big Dipper, thus merged into esoteric scriptures. Several scriptures and ritual manuals transmitted to Japan by monks of the esoteric schools, such as the Hokuto shichisei nenju giki

6 The full title is Wenshushili pusa ji zhuxiansuoshuo jixiong shiri shan e suyao jing (J. Monjushiri bosatsu kyu shosen shosetsu Kikkyō jinichi zen'aku sukuyōkyō 文殊師利菩薩及諸仙所説吉凶時日善悪宿曜経), Taishō shinshū Daizōkyō (hereafter T.), 21, no. 1299.

7 Yano Michio, Mikkyō toseijutsu, Tokyo bijutsu, 1986, pp. 15-46.

8 The British Library, Or.8210/S 3326 (Ch.85.XIII). In Susan Whitfield with Ursula Sims-Williams (eds.), The Silk Road. Trade, Travel, War and Faith, London: The British Library, 2004, cat. no. 161.

Culture and Cosmos 
北斗七星念誦儀軌, ${ }^{9}$ the Hokuto shichisei goma hiyōgiki 北斗七星護摩秘要儀軌, ${ }^{10}$ the Hokuto shichisei enmei-kyō 北斗七星延命経, ${ }^{11}$ the Hokuto shichisei goma-ho 北斗七星護摩法, ${ }^{12}$ and the Shichisei Nyoirin himitsu yōkyo 七星如意輪秘密要経, ${ }^{13}$ all focus on the Big Dipper.

The introduction of these texts, and the dissemination of related rituals during the Heian 平安 period (794-1185) encouraged the belief in the seven stars as powerful forces that exerted a great influence on human destiny. The personified figures of the seven stars in the Hokuto shichisei enmei-kyo (Sutra of the Big Dipper for Prolonging Life) suggest that the stars were perceived as deities in the pantheon of the vast esoteric universe. ${ }^{14}$ According to this scripture, each of the seven stars was designated as the personal star on an individual by combining the zodiac signs under which people were born, as seen below:

Donrōshō 貪狼星 Rat

Komon shō 巨門星 Ox, Pig

Rokuzon shō 禄存星 Tiger, Dog

Mongoku shō 文曲星 Hare, Cockrell

Renchōshō 廉貞星 Dragon, Monkey

Mugoku shō 武曲星 Snake, Sheep

Hagun shō 破軍星 Horse

This combination indicates that the belief in stars was a fusion of astronomy, astrology, esoteric Buddhist theories, and the Chinese traditional understanding of the twelve animals of the zodiac. ${ }^{15}$ By the

9 T. 21, no.1305, pp. 423-3.

10 T. 21 , no. 1306 , pp. 424-5.

11 T. 21, no.1307, pp. 425-6.

12 T. 21 , no. 1310 , pp. 457-9.

13 T. 21 , no. 20,1091 , pp. 224-5.

14 T. 21 , no. 1307, p. 425 . 
tenth century in Japan, the belief in the personal stars became part of everyday life for aristocrats, as an entry from the diary of Fujiwara no Morosuke 藤原師輔 (908-60) reveals:

When I rise in the morning, firstly I recite the name of my star (honmyo sho 本命星) seven times. Next, I look into the mirror and the calendar to find out the fortune of the day. Then I wash facing west. Next I recite the name of the Buddha, followed by a prayer to the venerable shrines, and then I record the events from the day before. $^{16}$

The eclectic nature of religious practice in the Heian period is evident in these few lines, suggesting that individual's activities were very much dependant on a mixture of religious traditions and the good and bad astronomical signs specified in the calendar.

\section{The Japanese development of Star Rituals}

Monks of the Shingon and Tendai esoteric schools were responsible for introducing star-related rituals, which gained increasing support from the imperial house and aristocrats during the Heian period. By the end of the twelfth century, several kinds of star mandala were created in Japan. The image of the Big Dipper is placed prominently near the central deity in surviving examples, both the circular star mandala from the Tendai school, and the rectangular star mandala from the Shingon school. ${ }^{17}$ These mandalas were used as icons for rituals such as the Shijokō-hō (Rite of Blazing Light) 熾盛光法, the Hokuto-ku (Rite of the Big Dipper) 北斗供, the Sonjōō-hō (Rite of Sonjōō) 尊星王法, and the Nyoirin kashō-ku (Rite of stars for the bodhisattva Nyoirin) 如意輪加星供. Most of the surviving examples of the early star mandalas date from the twelfth and thirteenth centuries, suggesting the popularity of star-related rituals from the late Heian period to the Kamakura 鎌倉 period.

15 The most influential Daoist text for the development of combinatory belief was the Wuxing dayi (J. Gogyō taigi) 五行大義. Takeda Kazuaki, Hoshi mandara no kenkyū, Kyoto: Hozōkan, 1995, p. 84.

16 Fujiwara Morosuke, Kujō ujōshō yuikai (The Memoir of Kujō, The Great Minister of Right with Advice to Later Generation), in Nihon shisōshi taikei 8.

17 See the essay by Tsuda Tetsuei in this volume. 
In the medieval times, the Shijōkō-hō was one of the most important star-related rituals performed on Mount Hiei 比棎山, the principal sanctuary of Tendai Buddhism. It was performed especially at times of unusual astronomical movements such as solar and lunar eclipse, or at times of natural calamities, for the purpose of ensuring the well-being of the emperor. According to the Asabashō 阿婆縛抄, a Kamakura period ritual collection compiled by the Tendai monk Shōchō 承澄, the Shijōkōhō was performed only 54 times between 845 and 1305. The Tendai Abbot Jien 慈円 (1155-1225) was a particularly ardent practitioner of this rite, and in 1205 commissioned the construction of the temple Daishihōin 大織法院 with a purpose-built hall called Shijōkō-dō (Hall of Blazing Light). The Shijōkō-hō was performed by Jien in this hall for the benefit of the retired emperor Gotoba-in 後鳥羽院 in 1206, 1207, and 1208. ${ }^{18} \mathrm{~A}$ description included in the ganmon 願文 (vow) of Gotoba, as recorded in the Monyōki 門葉記, provides a valuable insight into the icons that were displayed in the hall and the rituals that took place there:

The Shijōkō-dō has three bays on all four sides. The main icon is a gilt bronze seed-letter (shuji 種字) symbolizing the Golden Wheel Buddha Ichiji Kinrin 一字金輪, and measuring eight shaku 尺 (appx $2.5 \mathrm{~m}$ ). [The following images are also in the hall:] the Buddha Yakushi 薬師如来 (Sk. Bhaisajyaguru) with the bodhisattvas Nikkō 日光 and Gakkō 月光 (Sk. Suryaprabha, Candraprabha) and the Twelve Guardians (Jūni shinshō 十二神将); Fudō Myōō (Sk. Acalanatha) 不動明王 with two young attendants; Bishamon-ten (Sk. Vaisravana) 毘沙門天) and Kichijō-ten (Sk. Mahasri) 吉祥天, the 'original buddhas and bodhisattvas' (honjibutsu-bosatsu 本地仏菩薩 of Hiei; and five mandalas: one Mandala of the Buddha of the Seed Syllable Golden Wheel and Buddha-eye (Ichiji kinrin Butsugen 一字金輪仏眼), one Big Dipper Mandala, one Mandala of the Two Worlds 両界曼茶羅, one Lotus Sutra Mandala 法華曼茶羅, and one Assembly of Emptiness Mandala (Kokū-e mandara 虚空会曼茶羅).

18 Satō Masato, 'Sannō Shintō keiseishi no ippan', Shūkyō kenkyū 266 (1985), p. 44. 
Apart from everyday services, the Rite of the Blazing Light (Shijōkō-hō), the Rite of the Buddha Seed Syllable Golden Wheel and Buddha Eye (Ichiji kinrin butsugen), the Rite of the Medicine Buddha (Yakushi-hō), the Rite of the Lotus Sutra (Hokke-hō), and the Fire ritual of the Immovable King of Light (Fudō Goma 不動護摩) are performed annually, each lasting seven days. In addition, the Service for the seventy Heavenly Beings (Shichijūten$\mathrm{ku}$ 七十天供) is held on the first day of the month, and a service for the kami Sannō (Sannō-ku 山王供) is held on the last day of the month.' 19

We should note that images of the 'original buddhas and bodhisattvas (honjibutsu-bosatsu) of Hie' were included along with esoteric Buddhist images, and the Sannō-ku service for the kami of the Hie Shrine was performed in the hall. The inclusion of these Japanese deities and the ritual for the Sannō kami indicate that new additions and variations to esoteric rites transmitted from China developed in Japan by the thirteenth century.

It is not possible to determine from the description above if the images in the hall were sculptural or pictorial, but an example of Hie-Sannō honjibutsu mandara (fig. 3) from the early Kamakura period, now in the Nezu Institute of Art, Tokyo, provides some idea as to what the 'original buddhas and bodhisattvas' may have looked like. This mandara depicts seventeen figures of Buddhas, bodhisattvas and other esoteric deities, painted in bright pigments and embellished with cut gold decoration on silk which is pasted onto simple wooden panels in the form of a zushi 厨子 (portable shrine with doors). At first glance, the mandara projects the impression of a purely Buddhist work, yet a closer inspection of the cartouches inscribed next to each deity reveals that the deities are indeed honjibutsu-bosatsu, that is, the Buddhist essence of the kami of the Hie Shrine.

The identification of Japanese kami with their Buddhist 'original ground' (honji) was a widespread phenomenon in pre-modern Japan, when esoteric monks consciously accommodated the local belief into the Buddhist theoretical framework. The appropriation of the ancient kami of the Hie Shrine as the guardians of the newly established Buddhist temple on Mount Hiei in the late eighth century by Saichō 最澄 (767-822), the founder of the Japanese Tendai school, paved the way for the

19 Monyōki 134, compiled by Son'en, T. zuzō 12, pp. 313-4. 
development of the theory of honji-suijaku 本地垂迹 (origin and traces), which from a Buddhist perspective interpreted the local deities as temporary manifestations (traces) of the Indian Buddhas (origin).$^{20} \mathrm{By}$ the end of the Heian period, each Japanese kami was systematically paired with their Buddhist counterparts, and shrines and temples functioned in close associations. This uniquely Japanese situation encouraged the development of visual representations which are generally described in modern terms as 'Shinto mandara' or 'Suijaku (trace) mandara', and which graphically illustrate the complex fusion of religious ideas in premodern Japan.

\section{The seven shrines at Hie}

The Hie 日吉 Shrine (sometimes pronounced Hiyoshi), situated at the north east foot of Mount Hiei, remains today as one of the most important ancient shrines in Japan with over 3,800 subsidiary shrines scattered all over Japan. The present day Hie Shrine complex occupies an area of approximately 400,000 sq.m., in which seven principal shrines and numerous smaller shrines are dotted among the wooded natural environment. The present shrine buildings were constructed in the late sixteenth century after a catastrophic fire destroyed the entire templeshrine complex on Mount Hiei in 1571, but the style of architecture retains the distinct style of Hie, with the raised floor supported on pillars and the curved roof with over-hanging eaves (Fig. 4). The shrine flourished in association with the Enryaku-ji 延暦寺 temple on Mount Hiei, and at the height of its prosperity during the medieval period, there were 108 shrines altogether within the complex, with twenty-one principal shrines that were organized into three groups: the Upper Seven 上七社, Middle Seven 中七社 and Lower Seven 下七社. ${ }^{21}$

The origin of the shrine goes back to the local belief in the kami of the mountain Ōyamakui no kami 大山昨神. Archaeological evidences suggest that the early worship of kami began to be performed at this location from at least the third or fourth centuries CE. According to the

20 The concept of origin and trace is analogous to the interpretation of the structure of the Lotus Sutra, the principal scripture of Tendai Buddhism, which is divided in two parts, honmon 本門 (origin) and shakumon 迹門 (trace).

21 The number 108 corresponds to the number of spiritual impediments that have to be overcome by Buddhists, indicating a strong Buddhist theoretical input in the development of the shrine. 
oldest surviving shrine record, Hiesha negi kudenshō 日吉社禰宜口伝抄, dated 1047, another kami, Ōnamuchi no kami 大己貴神 from Mount Miwa 三輪, was solicited to this location during the reign of Emperor Tenji 天智 in the seventh century, and two shrine buildings were constructed in $669 .^{22}$ The shrine legend claims that the third shrine, Jūzenji 十禅師, was established when a kami called Jūzenji manifested himself in the form of a young boy in front of Saichō in 785, but as there is no contemporary textual evidence for this claim, it is more likely that the story was a later invention. Such legends highlight the problem of researching the history of shrines in general, since the origins of shrines were written long after the actual events. Saichō is also considered to be the patriarch who named the multiple kami of Hiei with the collective term Sannō, literally 'Mountain King. ${ }^{, 23}$

The historical record indicates that the Hie Shrine was included in the system of the twenty-two imperially supported shrines in 1039, and the first imperial visit to the shrine, by Emperor Gosanjo 後三条, took place in $1072 .^{24}$ This was the period when the shrine developed rapidly as a result of the climate of kami-buddhas combination (shinbutsu shūgo 神仏習合). By the time the afore mentioned Hiesha negi kudenshō was written in 1047, there were seven principal shrines with many more subsidiary shrines within the shrine complex, but not all the twenty-one shrines are mentioned at this stage. The first textual reference to the organization of the Hie Shrine in three groups of seven appears in the Yōtenki 燿天記, one of the most reliable early records on the Sannō Shinto, dated to 1223. The appellation of the Upper, Middle and Lower Seven shrines appear in this manuscript in reference to the court ranks bestowed to the kami. ${ }^{25}$ According to this record, the hierarchical

22 Hiesha negi kudenshō, Shintō taikei 29 (Jinja-hen), p. 3.

23 The adoption of the name Sannō originates from the legendary Chinese deity 'Mountain King' of Mount Tiantai. In the medieval period Sannō was regarded as the protector of three sacred mountains, the Vulture Peak in India, Mount Tiantai in China and Mount Hiei in Japan. Cf. Hiesha Shintō himitsuki (1571), by the shrine priest Hafuribe Yukimaro, in Shinto taikei 29, p. 331.

24 Ōmi meisho zue, in Nihon meisho füzoku zue 11, p. 66.

25 Yōtenki, in Shintō taikei 29, pp. 47-8.

Culture and Cosmos 
organization of the twenty-one shrines was well established by the first quarter of the thirteenth century, and we can assume that the grouping developed sometime between the second half of the eleventh century and the first quarter of the thirteenth century. This coincides with the time when the star rituals and star mandalas were widely circulated.

\section{Seven Stars of Heaven and Seven Shrines on Earth}

One of the earliest textual references to the identification of seven shrines at Hie with the seven stars appears in the thirteenth century text Sanke yōryakki 山家要略記 (Short History of the Mountain Lineage). This includes a passage, attributed to the Tendai monk Ryōgen 良源 (912985), which states: 'The seven Big Dipper stars of Yang, the seven shrines of Yin. ${ }^{26}$ Mention of Ryōgen suggests that the association was already made in the tenth century, but as there is no other reference from such an early period exists, it is safer to assume that this identification was contemporary to the text. A description that more explicitly connects the shrines with stars appears in the Keiran shȳyosh $\bar{u}$ 渓嵐拾葉集, the encyclopaedic compilation of Tendai theories and historical records by the monk Kōshū 光宗, completed around 1348. The passage 'There are Seven Stars of the Big Dipper in Heaven, and Seven Sannō Shrines on Earth' 在天北斗七星、在地山王七社 clearly indicates that the connection was established by the fourteenth century. ${ }^{27}$

The identification of seven stars with the seven shrines is graphically explained in one of the drawings included in a set of eighteen large hanging scrolls, the Sannō nijüissha tōezu 山王二十一社等絵図 (Fig. 5). The scrolls were commissiond in 1579 by the shrine priest Hafuribe Yukimaru 祝部行丸 in his attempt to prevent the loss of century-old customs and traditions of the Hie Shrine after the fire. In this drawing, the geographical position of the seven shrines is sketched in a simplified diagram just below the diagram of the constellation, clearly pointing to the similarity of the shapes. A short caption next to the constellation reads: 'There are seven stars of the Big Dipper in Heaven, the personal stars of the human destiny' 在天北斗七星、人身本命星. Another caption by the diagram of shrines states: 'There are seven Sannō shrines on earth, the personal kami of the human destiny'

26 Takeda Kazuaki, Hoshi mandara no kenkū, p. 40.

27 Kōshū, Keiran shūyoshū, T. 76, p. 515. 
在地山王七社、人身本命神. These descriptions explicitly convey the relationship between stars and shrines, which were both seen to exert a great influence upon the individual's destiny.

Apart from textual references, several examples of Hie-Sannō mandara dating from the thirteenth century onwards provide visual evidence connecting the seven shrines at Hie to the Big Dipper. Here I shall consider one example, the Hie-Sannō mandara from the Saikyō-ji temple 西教寺, Shiga prefecture (Fig. 6). At the top section of this long silk hanging scroll $(124 \times 40 \mathrm{~cm})$, the constellation of the Big Dipper is represented by figures wearing a Chinese costume inside lunar discs. This kind of representation of the seven stars conforms to the iconography employed for many of the star mandalas, for example the twelfth century circular star mandala from the Hōryū-ji temple, and the rectangular star mandala from the Kumeta-ji temple 久米田寺, Osaka. ${ }^{28}$ The source for the iconography of the stars of the Big Dipper as exotic figures inside lunar discs can be found in the twelfth century esoteric text Kakuzenshō 覚禅抄, which describes these figures in the style of demon-like creatures called yasha 夜叉 with red hair, wearing crowns and fine jewellery. ${ }^{29}$

In the Saikyō-ji mandara, fifteen figures of kami in their suijaku form, that is, in their manifestation as Japanese deities, are arranged symmetrically in a shrine-like interior below the constellation. The stairs in the lower centre indicates the distinct architectural style of the Hie Shrine. While some mandara, such as the Nezu example, adhered to the Buddhist iconography and depicted the kami as Buddhist deities (honjibutsu), others, such as this Saikyō-ji example, depicted the kami as Japanese deities (suijaku) by employing iconographical patterns invented in Japan. Unlike canonical esoteric Buddhist iconography, which allows easy identification of each deity from their hand gestures and attributes, the iconography of Japanese kami often presents problems of identification. In most cases, Japanese kami were portrayed in generic forms, either as a monk (sogyo 僧形), or as male or female aristocrats in Heian court dresses. In the Hie-Sannō mandara, though, it is possible to identify all twenty-one kami from sets of iconographical drawings included in the Hie Sannō Gongen chishinki 日吉山王権現知新記, an

An illustration of this mandala is included with Tsuda's essay (Fig. 26) in this volume.

29 Kakuzen, Kakuzenshō, T. zuzō 5 p. 398.

Culture and Cosmos 
Edo period study of medieval Hie-Sannō belief, compiled by Gōkan 豪観, a monk of the Keisoku-in temple 鶏足院 in the Yokawa 横川 area of Mt Hiei. ${ }^{30}$

In the Saikyō-ji mandara, the kami of the Upper Seven shrines are depicted in the upper half of the composition, with the principal deity Ōmiya (Ōnamuchi no kami) in the centre flanked by the other six kami. In the lower half of the composition, five deities from the Middle Seven shrines and three from the lesser shrines are depicted in slightly smaller scale. The iconography of the kami of the Upper Seven shrines is consistent in all surviving Hie-Sannō mandara except for the central deity Ōmiya, who is sometimes depicted as a monk, other times (as in the case of this Saikyō-ji mandara) as an exotic figure wearing a red Chinese-style garment and a golden crown. This rather unusual iconography for a Japanese kami is no doubt connected to the stars, as it clearly points to similar iconographical descriptions of the Big Dipper in the Kakuzenshō and the representation of the Big Dipper in lunar discs in star mandalas.

Only one out of seven principal kami is depicted as a secular courtier, while three are depicted as monks, and two as female deities. Unlike the conventional Japanese Heian court ladies, these female kami are depicted in Chinese-style dress with golden head ornaments, similar to the appearance of Buddhist female deities such as Kichijō-ten and Benzaiten, reflecting the strong Buddhist influence exerted upon the development of iconography at Hie.

In the lower section of the mandara, the most prominent female deity dressed in red in the centre can be identified from the iconographical drawings included in the above mentioned Hie-Sannō Gongen chishinki as the kami of one of the Middle Seven shrines, Shitaterunime no kami 下照姫神 of the Seijo 聖女 Shrine. The attribute she holds is a Buddhist nyoi hoju 如意宝珠 (a wish-fulfilling jewel), which also connects her to her Buddhist honji identity Nyoirin Kannon 如意輪観音 (Sk. Cintamanicakra). Singling out this deity from the Middle Seven shrines and placing her in a prominent position in the centre, immediately below the main deity Ōmiya, suggests that the Seijo shrine played an important role in the ritual for which this mandara was created. The association of Nyoirin Kannon with the seven stars of the Big Dipper can be found in the sutra Shichisei Nyoirin himitsu yōkyō; the ritual Nyorin kashō-ku was one of the Tendai services related to stars, and was performed in order to

30 Gōkan, Hie-Sannō Gongen chishinki, in Shintō Taikei 29, p. 471.

Culture and Cosmos 
protect individuals from misfortune. ${ }^{31}$ The presence of the Seijo Shrine in a prominent position, together with the image of the Big Dipper and the iconography of Ōmiya in Chinese robe, indicates that this mandara was created for star-related rituals.

Several other examples of medieval Hie-Sannō mandara survive today, which also depict the kami of the Seijo Shrine in the central position, suggesting the significance of this shrine in the Hie-Sannō belief system in the medieval period. Yet previous studies have offered no explanation of why this shrine was singled out in some medieval mandara, nor has any connection of the Seijo kami with stars been acknowledged. In the aftermath of the official separation of Shinto and Buddhism (shinbutsu bunri 神仏分離) enforced by the Meiji government in 1868, all twenty-one shrines at Hie were re-named with more purely Shinto names, playing down the old Buddhist connection. Ōmiya, the principal shrine, was re-named Nishi hongū 西本宮 (Western Main Shrine), and Ni no miya 二宮, where the local kami, Ōyamakui no kami, is enshrined, became Higashi hongū 東本宮 (Eastern Main Shrine). Seijo Shrine was re-named Usa Wakamiya 宇佐若宮, a name that is generally associated with a young male kami. With the change of the name, the gender of the kami was switched, and Seijo's association with her honji Nyoirin Kannon and the wish-fulfilling jewel was obliterated from people's memory. The present day Usa Wakamiya Shrine is a small unassuming building, standing modestly beside one of the seven main shrines, and no specific ritual is held at this shrine.

\section{Epilogue}

In 1571, the fire set by the warlord Oda Nobunaga's 織田信長 army destroyed the entire temple-shrine complex on Mount Hiei. Nobunaga's determination to eliminate all opposition to his authority targeted this powerful, wealthy, and independent religious institution, and its destruction signalled the arrival of a new era. All shrine buildings at Hie were razed to the ground, along with temples on Mount Hiei. A large number of lives were also lost: innumerable works of religious art and historical manuscripts also perished in this fire, which partly explains the relative rarity of Hie-Sannō mandara today.

31 Tendai mikkyō no hon, Books Esoterica 21, 1998, p. 216.

Culture and Cosmos 
Further damage was inflicted on the shrine in the late nineteenth century after the official separation of Shinto and Buddhism in 1868, and many Buddhist-related artefacts were destroyed in the storm of the antiBuddhist iconoclastic movement (haibutsu kishaku 廃仏毀釈) that followed. The damage was particularly serious at Hie, due to the fact that a shrine priest, Juge Shigekuni 樹下茂国 (1822- 84) from the hereditary priest family, was an ardent supporter of the new policy. In October 1870 , all Buddhist artefacts in the shrine were eradicated and thrown on a bonfire that burnt for three days. ${ }^{32}$. The incident reminds us of the syncretic nature of rituals held at the Hie Shrine in the pre-Meiji period, and poses some questions. Where in the shrine did they perform Buddhist rituals? And where were these Buddhist icons and paraphernalia displayed?

These questions draw our attention to the unique architectural feature of the Hie Shrine, which is not easily noticeable by visitors today. As already pointed out, the architectural style of the Hie Shrine derives from the ancient granary with raised floor supported by pillars (the most famous example of this style is the Shōsō-in warehouse). Unlike the original raised floor structure, which has an empty space between the supporting pillars, at Hie the space below the floor is surrounded by wooden walls on four sides. The dark enclosed space, geden 下殿 (literally, 'lower palace'), is high enough for an adult to stand upright, and it is accessible only through a door under the central stairway (Fig. 7). ${ }^{33}$ The sacred ground directly below the innermost room of the shrine above is exposed. In the pre-Meiji period, there was an altar at the back where Buddhist images were displayed, and Buddhist services were held here. ${ }^{34}$ References to geden can be found in medieval texts, indicating that this feature has been an integral part of the Hie style in the medieval buildings as well. Textual sources also indicate that Buddhist services such as the so-called Eight Lectures on the Lotus Sutra (Hokke hakkō 法華八講) were regularly performed by the Tendai monks of Mount Hiei at the shrine. ${ }^{35}$ Star-related rituals may have been one of the services held in this space.

32 Meiji nyūsu jiten, Mainichi communication, 1983, p. 338.

33 For floor plans and the architectural details, see Sagai Tatsuru, Hie Taisha to Sannō Gongen, Jinbun shoin, 1992, pp. 140-71.

34 Hie Taisha, Jinja kiko 14, Gakushū kenkyūsha, 2003, p. 7.

Culture and Cosmos 
The Hie Shrine was officially separated from the Enryaku-ji temple in 1871 , and although the organization of the twenty-one shrines in three groups of seven was retained, its connection with the Big Dipper was ignored, since the Buddhist contribution to the shrine was no longer relevant to the new 'pure' Shinto. The present day Hie Shrine retains rare Buddhist connections a few times a year: in May it hosts the annual ritual Sannō-kō, a lecture on the Lotus Sutra performed by monks of the Enryaku-ji temple; and monks also participate in the annual Sannō festival in April. However, no Buddhist artefacts remain in the shrine, and the geden is a non-functional space. A far-reaching effect of the Meiji government's policy to promote Shinto as national religion can be surmised by the fact that little attention has been paid to the study of medieval associative cults until relatively recent times. The belief in the Big Dipper and the identification of stars with the seven shrines at Hie need to be re-considered in the context of the complex fusion of medieval religious traditions, and draws our attention to the significant role that stars played in pre-modern Japan.

Fig. 1 Diagram of a terrapin-shaped serpentine lidded vessel, inlaid with gold and silver. It shows the constellation of the Big Dipper on its back. $15 \times 10 \mathrm{~cm}$. Eighth century, Shōsō-in.

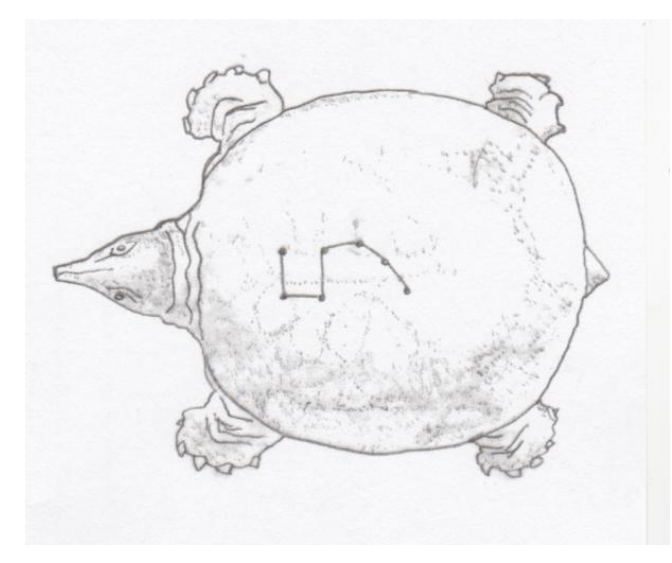

35 For example, Hie Sannō rishōki mentions that Fujiwara no Yorimichi's mother made vows to sponsor the Lotus Sutra lectures and to stay in the geden to pray in seclusion if the kami Sannō would spare her son's life from the illness. Zoku Gunsho ruijū vol. 51, 1936, pp. 654-706. 
Meri Arichi 211

Fig. 2 Detail from a Chinese star chart from Dunhuang, showing the section of the northern circumpolar region. Tang dynasty (618-906), The British Library.

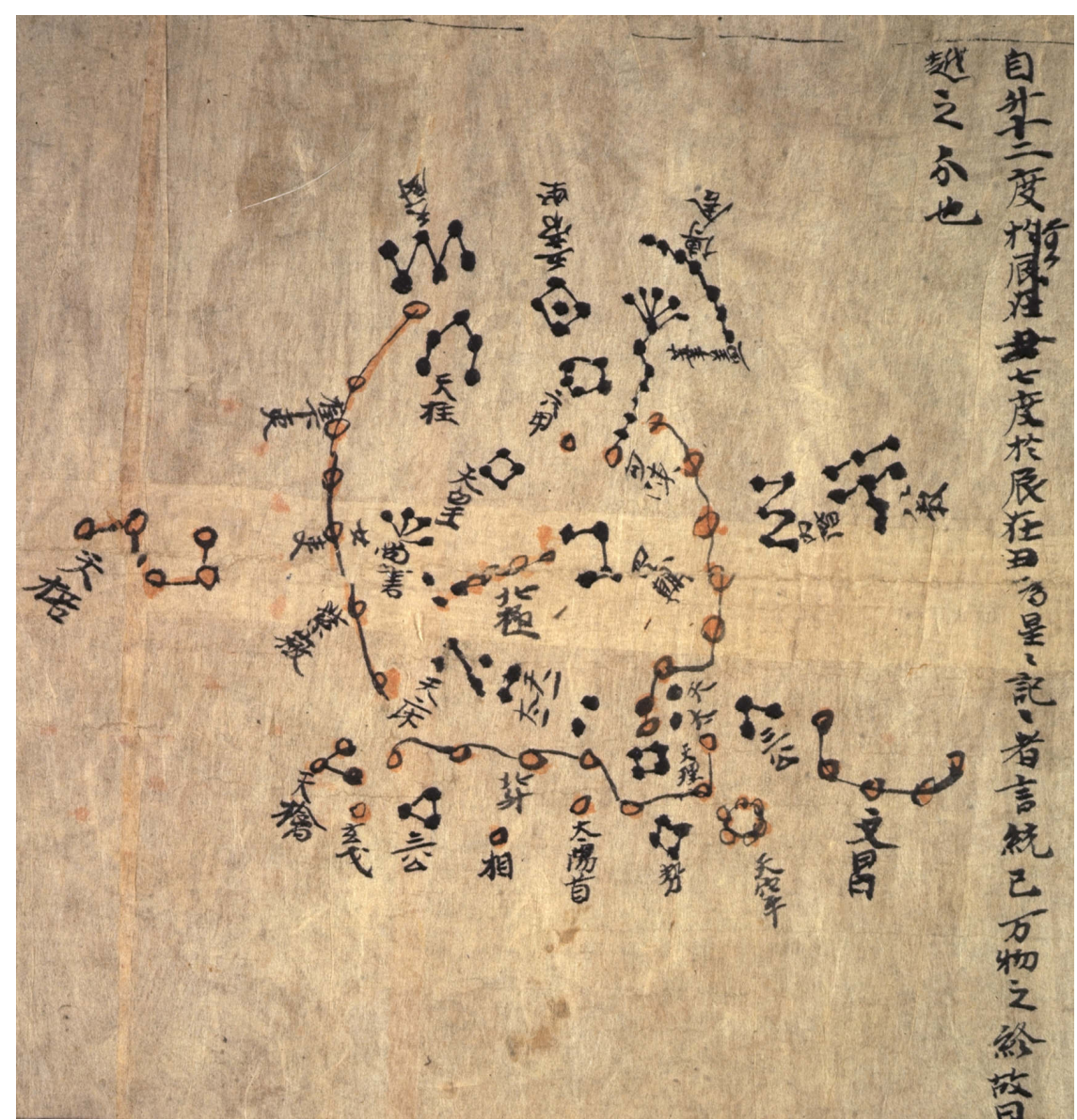


212 Seven Stars of Heaven and Seven Shrines on Earth

Fig. 3 Honjibutsu Mandara. Colour and gold on silk. Kamakura period (1185-1333), Nezu Institute of Art, Tokyo.

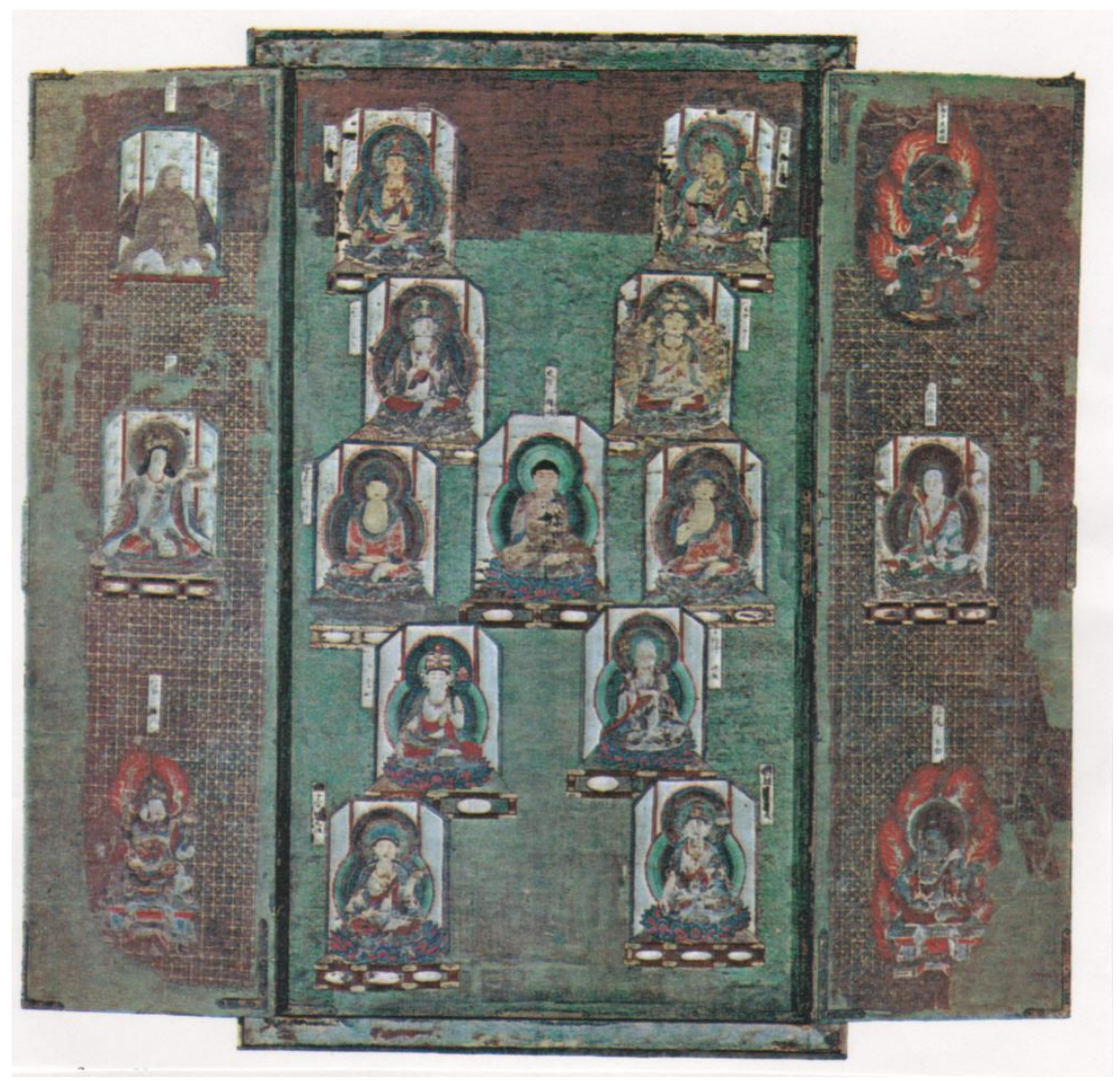

Culture and Cosmos 
Meri Arichi 213

Fig. 4 The present day Nishi hon-gu (Ōmiya Shrine), Shiga prefecture.

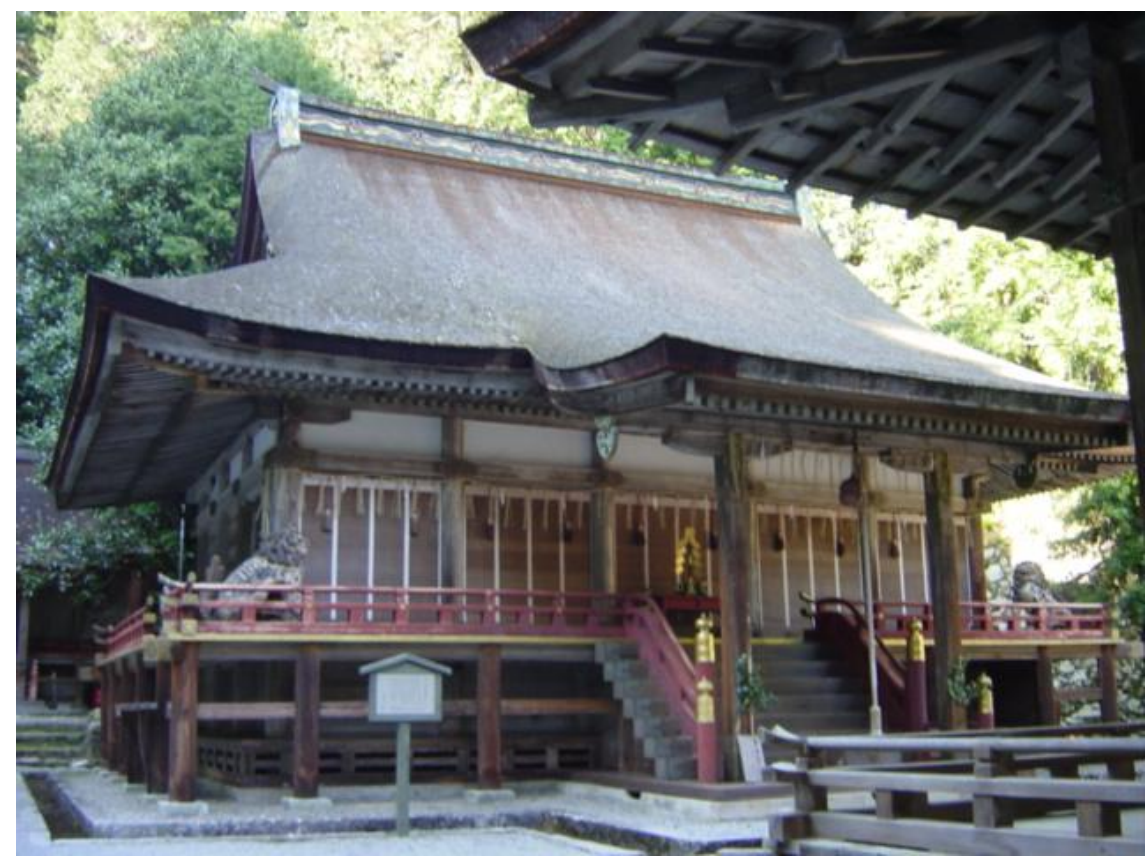


Fig. 5 Sanno Nijüissha tōezu, a diagram of the constellation of the Big Dipper and the geographical position of the shrines at Hie. $16^{\text {th }}$ century, Eizan bunko, Sakamoto.

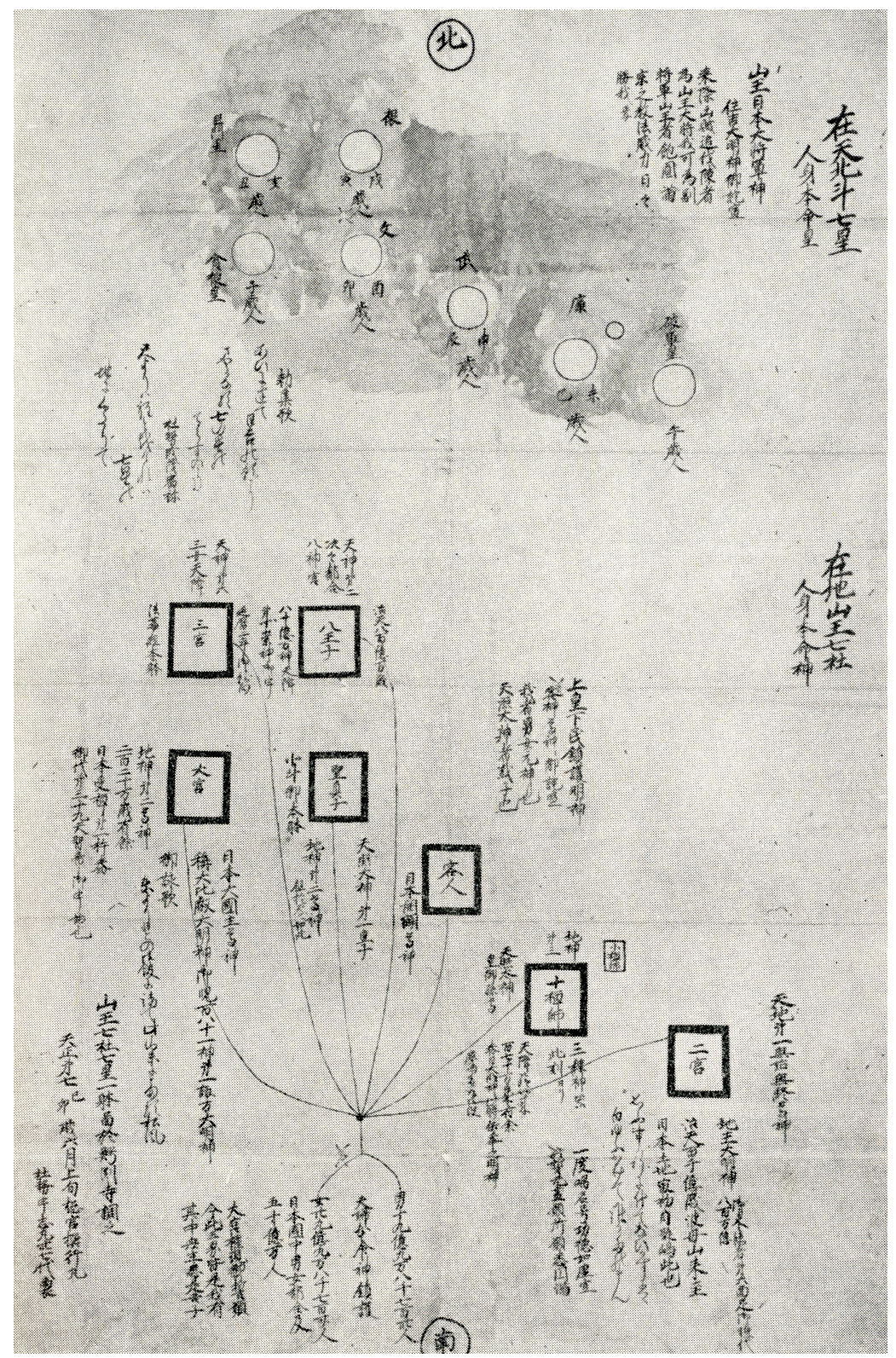

Culture and Cosmos 
Meri Arichi 215

Fig. 6 Hiei Sannō Mandara The Big Dipper is depicted in the upper section. Kamakura period, Saikyō-ji, Shiga prefecture.

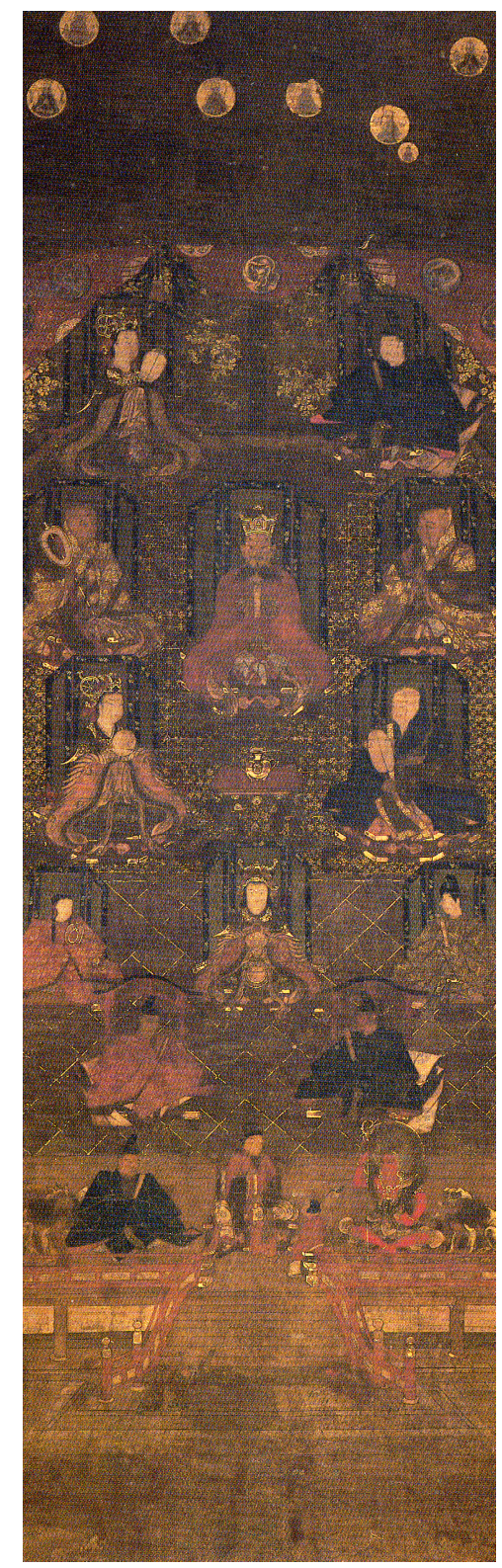

Culture and Cosmos 
216 Seven Stars of Heaven and Seven Shrines on Earth

Fig. 7 Geden, the door under the front stairs of the Nishi hon-gu, Hie Shrine.

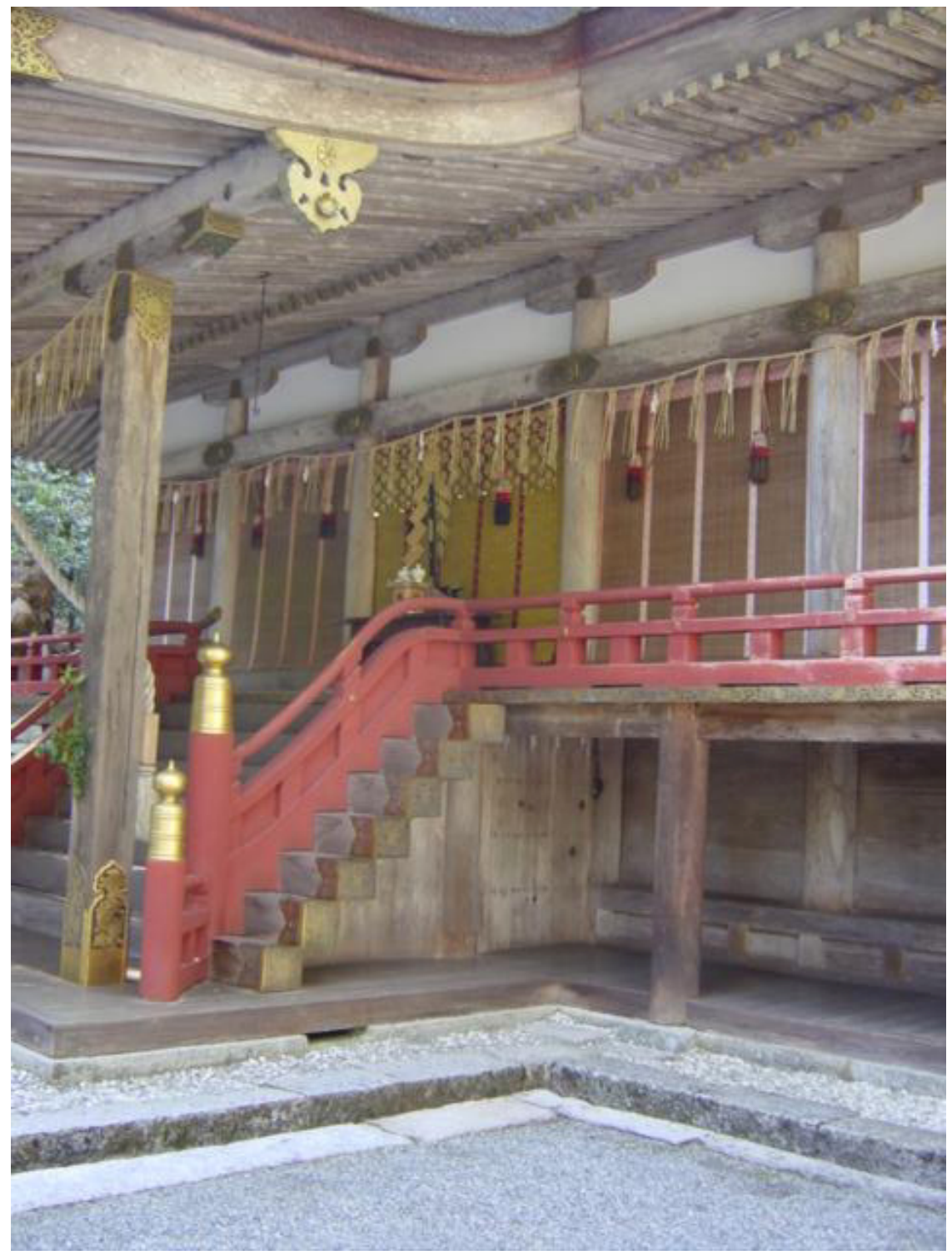

Culture and Cosmos 